\title{
Analisis Perilaku Belanja Online Selama Masa Pandemi COVID-19
}

\author{
Received: \\ 29 Oktober 2020 \\ Revision \\ received: \\ 23 November \\ 2020 \\ Accepted: \\ 25 November \\ 2020 \\ Nugroho Hardiyanto*, Arie Indra Gunawan, Wahyu Rafdinal, Nur Choirul \\ Afif \\ Jurusan Administrasi Niaga, Politeknik Negeri Bandung, Indonesia

\begin{abstract}
:
Online shopping is currently an interesting phenomenon in Indonesia. The data shows that a very rapid development has occurred in terms of online consumers, especially during the Covid-19 pandemic. With the large number of consumers who cannot carry out daily activities or quarantine at home, making a significant increase in online shopping. It is important to know the behavior of online shoppers during the COVID-19 pandemic. This study uses structural equation modeling - Partial Least Square (SEM PLS) technique. The number of samples in this study is 214 respondents. The results of this study indicate that online shopping behavior during the COVID-19 pandemic is influenced by personal perception factors such as trust, comfort, convenience, and security. This research can provide benefits for companies or online stores in attracting consumers to shop during the Covid-19 pandemic
\end{abstract}

Keywords: trust, price, convenience, usefulness, safety, product quality, online shopping behavior

\begin{abstract}
Abstrak:
Belanja online saat ini menjadi fenomena yang menarik di Indonesia. Data menunjukkan perkembangan yang sangat pesat terjadi dari segi konsumen online, apalagi ketika masa pandemi covid-19. Dengan banyaknya jumlah konsumen yang tidak bisa melakukan aktifitas sehari-hari atau karantina dirumah, menjadikan peningkatan yang signifikan pada belanja online. Mempelajari perilaku konsumen perlu dilakukan karena berkaitan dengan keputusan pembelian. Tentunya hal ini menjadi penting untuk mengetahui perilaku pembeli online selama masa pandemi COVID-19. Penelitian ini menggunakan teknik analisis structure equational model - Partial least square. Jumlah sampel dalam penelitian ini adalah 300 sampel. Hasil penelitian ini menunjukan bahwa perilaku belanja online pada masa Pandemi COVID-19 dipengaruhi oleh factor persepsi pribadi seperti kepercayaan, kenyamanan, kemudahan, dan keamanan. Penelitian ini dapat memberikan manfaat bagi perusahaan atau toko online dalam menarik konsumen untuk berbelanja selama pandemic Covid-19
\end{abstract}

Kata kunci: kepercayaan, harga, kenyamanan, kemudahan, keamanan, kualitas produk, perilaku belanja online

\section{Pendahuluan}

Perkembangan dunia usaha dan perdagangan saat ini tidak lepas dari kemajuan teknologi khususnya teknologi informasi dan e-commerce, dimana sekarang konsumen tidak perlu repot ketika ingin berbelanja tetapi tidak punya banyak waktu untuk datang langsung ke toko (offline) cukup menggunakan smartphone maka konsumen sudah bisa memesan produk yang diinginkan. Perkembangan pertumbuhan e-commerce ini tiap tahun semakin bertambah. Data dari APJII (2019) menyebutkan tahun 2019 tercatat sebanyak 171 juta pengguna internet di Indonesia, setidaknya setiap tahun terjadi peningkatan pengguna internet tumbuh $10,2 \%$ atau bertambah sebanyak 27 juta jiwa. Dari 171 juta pengguna internet itu 64,8\% digunakan untuk mengakses hiburan (video dan film), selanjutnya 
diposisi kedua dengan persentase 17,1\% menggunakan internet untuk gaming (game), kemudian 14\% menggunakan untuk e-commerce atau berbelanja online pakaian, buku, dan aksesoris. Selanjutnya Keminfo juga menyebutkan media sosial yang paling banyak diakses 50,7\% Facebook, disusul instagram 17,8\% dan Youtube 15,51\%. Berdasarkan angka diatas kita bisa mengetahui bahwa dari pengguna internet aktif pada tahun 2019 sebanyak 171 juta menggunakan e-commerce sebesar $14 \%$ atau 23,94 juta, angka ini cukup besar ditambah lagi dengan masa pandemi COVID-19 dimana masyarakat selaku konsumen melakukan karantina dirumah, maka diprediksi terjadi kenaikan yang signifikan pada belanja online.

Keuntungan menggunakan e-commerce yaitu memungkinkan organisasi meningkatkan pertumbuhan ekonomi, meminimalisir hambatan untuk dapat beredar di pasaran, meningkatkan efesiensi dan efektivitas, dan mengurangi biaya dalam memasarkan produknya. Sedangkan keuntungan yang didapat oleh konsumen yaitu memberikan kenyamanan dalam memilih produk, mendapat lebih banyak pilihan untuk produk dan layanan, serta tidak membuang waktu yang berlebih (Ollie, 2008). Akibat Pendemi COVID-19 banyak sektor usaha yang awalnya beroperasi secara offline dituntut untuk beroperasi secara online. Hal ini menarik untuk dicermati apakah ketika masa pandemi COVID-19 terjadi peningkatan pembelian online.

Banyak penelitian terdahulu yang telah menganalisis factor yang mempengaruhi perilaku belanja konsumen. Salah satunya adalah factor persepsi pribadi seperti kepercayaan, kenyamanan, kemudahan, dan keamanan. Ataupun factor penyedia produk seperti kualitas produk dan harga. Kepercayaan, kenyamanan, kemudahan, ataupun keamanan dapat mempengaruhi perilaku seseorang dalam berbelanja (Cozzarin \& Dimitrov, 2016; Moeller et al., 2009; Tasin, 2017). Dalam factor penyedia produk, kualitas produk yang diberikan kepada consumers akan mempengaruhi keputusan dalam membeli produk (Lee et al., 2017). Pada harga, harga adalah salah satu alasan terpenting konsumen tetap menggunakan penyedia saat ini atau beralih ke penyedia lain (Han, 2015). Tetapi belum ada penelitian sebelumnya menganalisis keseluruhan factor tersebut dalam perilaku belanja online pada situasi khusus yaitu pandemic Covid-19. Sehingga, penelitian ini penting untuk dilakukan karena akan memberikan pengetahuan baru dalam literatur perilaku belanja online.

Penelitian ini memilih konteks pada masyarakat Indonesia. Terdapat beberapa alasan dipilihnya Indonesia karena berdasarkan hasil listing di 3.504 Blok Sensus BPS (Badan pusat statistic), tercatat sebanyak 15,08 persen usaha yang melakukan penjualan barang/jasa melalui internet, dari jumlah yang tercatat tersebut, sebanyak 72,83 persen usaha melakukan penjualan barang/jasa melalui internet. Selain itu, Sebagian besar usaha mulai melakukan penjualan secara online pada tahun 2017 sampai dengan tahun 2018 yaitu sebanyak 45,31 persen (Badan Pusat Statistik, 2019). Dilihat dari prospek yang besar dalam lingkungan bisnis, maka penting untuk menjadikan konsumen Indonesi sebagai responden penelitian ini. Sehingga dapat memberikan pemahaman mengenai perilaku belanja online pada konteks negara berkembang seperti Indonesia.

Penelitian ini mengeksplorasi faktor-faktor yang dapat mempengaruhi seseorang dalam berbelanja online pada masa pandemic Covid-19. Perilaku belanja online dapat ditentukan dari factor persepsi pribadi seperti kepercayaan, kenyamanan, kemudahan, dan keamanan. Ataupun factor penyedia produk seperti kualitas produk dan harga.

\section{Kajian Literatur}

\section{Perilaku Belanja Online}

Pengambilan keputusan diawali dengan adanya kebutuhan yang berusaha untuk dipenuhi. Pemenuhan kebutuhan ini terkait dengan beberapa alternatif sehingga perlu dilakukan evaluasi yang bertujuan untuk memperoleh alternatif terbaik dari persepsi konsumen. Perilaku pembelian merupakan hasil dari rangkaian kegiatan yang dilakukan konsumen dalam mengidentifikasi kebutuhan, mencari informasi, mengevaluasi beberapa alternatif, dan memilih yang tepat (Rafdinal, 2019). Dalam model pengambilan keputusan konsumen terdiri dari enam variabel yang saling terkait: pesan, pengenalan merek, sikap merek, kepercayaan diri, niat dan pembelian (Howard, 1989). Selain itu, pengambilan keputusan 
pembelian juga ditentukan oleh promosi toko, suasana, tingkat kebersihan, tingkat layanan, harga, nilai, kenyamanan logistik, dan pengalaman ritel (Blackwell et al., 2006). Dalam pengambilan keputusan pembelian, konsumen akan mengevaluasi kinerja produk dengan menilai fitur tambahan (Lew \& Sulaiman, 2014). Keputusan untuk berbelanja online adalah kecenderungan seseorang untuk melakukan pembelian melalui internet. Kecenderungan yang dimaksud adalah mengalami melalui proses pembelian dari tahap pencarian ke tahap keputusan pembelian, tidak hanya niat untuk melakukan pembelian online. Secara khusus, dalam proses pembelian konsumen, keputusan untuk berbelanja online terletak pada tahap evaluasi alternatif, karena pada tahap ini konsumen memilih atribut produk apalagi pada masa pandemic Covid-19 yang lebih meningkatkan keputusan seseorang untuk berbelanja secara online.

\section{Kepercayaan, Kenyamanan, Kemudahan, dan Keamanan}

Kepercayaan. Salah satu factor persepsi pribadi adalah kepercayaan. Dalam transaksi online, kepercayaan muncul ketika mereka yang terlibat telah mendapatkan kepastian dari pihak lain, serta bersedia dan mampu memenuhi kewajibannya. Kepercayaan yang dipengaruhi oleh kualitas informasi, review pembelian sebelumnya, dan kualitas situs online berpengaruh terhadap Keputusan Pembelian online (Tasin, 2017). Kepercayaan juga ditentukan dari keakraban dengan merek yang kemudian mempengaruhi keputusan dalam membeli (Hosseini \& Norouzi, 2017). Kepercayaan juga ditentukan dari pengetahuan dan aktivitas belanja online (Wang \& Chen, 2009). Tetapi, membangun kepercayaan bisa jadi sulit dalam situasi online dan pandemic Covid-19 yang diperlukan analisis lebih lanjut dalam pengaruh terhadap perilaku pembelian. Dari sisi individu, orang yang lebih tahu tentang belanja online akan lebih percaya dan bersedia berbelanja secara online. Terdapat pengaruh yang signifikan media sosial terhadap perilaku pembelian pakaian online dengan kepercayaan sebagai elemen yang paling signifikan dipengaruhi oleh persepsi risiko dan perilaku pencarian informasi. (Chaturvedi et al., 2016). Lebih lanjut, penelitian lainnya juga menunjukan pengaruh kepercayaan terhadap keputusan membeli secara online (Mohmed et al., 2013). Sehingga, hipotesis yang dibangun sebagai berikut:

H1. Kepercayaan berpengaruh signifikan terhadap perilaku berbelanja online.

Kenyamanan. Awalnya, konsep kenyamanan dalam teori pemasaran melibatkan klasifikasi produk. Produk yang mudah digunakan adalah produk yang dirancang untuk meminimalkan waktu dan upaya yang diperlukan dari pelanggan untuk membeli dan memiliki produk (Yale \& Venkatesh, 1986). Berry et al. (2002) dan Seiders et al. (2007) secara ekstensif meninjau literatur tentang kenyamanan konsumen dalam ekonomi layanan dan mendefinisikan "kenyamanan layanan" sebagai persepsi waktu dan upaya konsumen terkait dengan pembelian atau penggunaan layanan. Beberapa penelitian terdahulu telah menganalisis dimensi layanan dalam perilaku pembelian. Dimensi kenyaman dalam perilaku pembelian terdiri dari lima jenis kenyamanan layanan, termasuk keputusan, akses, transaksi, manfaat, dan pascamanfaat (Jiang et al., 2013; Roy et al., 2016). Seseorang yang merasakan kenyamanan dalam berbelanja seacara online dapat mempengaruhi perilaku pembeliannya. Hal ini meruapakan hasil evaluasi dari manfaat yang dirasakan. Dengan demikian, hipotesis yang dinyatakan:

H2. Kenyamanan berpengaruh signifikan terhadap perilaku berbelanja online.

Kemudahan. Kemudahan dalam yang didapatkan selama proses berbelanja online dapat mempengaruhi perilaku seseorang dalam berbelanja. Kemudahan dalam konteks online mengacu pada tata letak sistem, urutan navigasi, dan kenyamanan untuk mencari produk atau informasi. Ini mirip dengan konsep "kenyamanan" yang diperkenalkan dalam Srinivasan et al. (2002) dan Rose et al. (2012). Aplikasi toko online yang memiliki berperforma buruk atau tidak memenuhi harapan konsumen untuk kenyamanan, akan membuat konsumen tidak puas sehingga akan mepengaruhi perilaku berbelanja kedepannya. Salah satu alasan utama bagi konsumen untuk berbelanja online adalah kemudahan (Agag \& El-Masry, 2016). Dengan kemudahan yang ditawarkan oleh aplikasi toko online akan membuat seseorang merasakan bahwa aplikasi tersebut bermanfaat dalam berbelanja sehingga akan mempengaruhi perilaku pembeliannya. Maka, hipotesis yang dibangun yaitu:

H3. Kemudahan berpengaruh signifikan terhadap perilaku berbelanja online. 
Keamanan. Pada tahap pembelian, konsumen harus mengetahui dengan baik rincian data pribadi dan pembayaran mereka tersimpan dengan aman. Tidak diragukan lagi, perilaku pembelian dapat menurun ketika dihadapkan dengan laporan media tentang pelanggaran keamanan ataupun data pribadi tidak dapat disimpan dengan baik oleh aplikasi toko online. Selain pelanggaran data, konsumen akan khawatir tentang situs web phishing, pencurian identitas, dan pencurian kartu kredit saat melakukan pembelian online (Cozzarin \& Dimitrov, 2016). Isu keamanan ini merupakan factor penting yang mempengaruhi perilaku pembelian. Penelitian sebelumnya menunjukkan bahwa ketika persepsi risiko keamanan dari situs toko online menurun, kepuasan dengan pembelian dari toko online cenderung meningkat (Szymanski \& Hise, 2000). Hal ini memberikan gambaran bahwa kemanan pada toko online dapat mempengaruhi pembelian seseorang di toko online. Sehingga, hipotesis yang dibangun sebagai berikut: H4. Keamanan berpengaruh signifikan terhadap perilaku berbelanja online.

\section{Product Quality and Price}

Produk dapat berupa benda atau jasa fisik yang ditawarkan kepada konsumen yang bersedia membayar (Išoraite, 2016). Kualitas Produk Salah satu keunggulan dalam persaingan ini terutama adalah kualitas produk yang dapat memenuhi keinginan konsumen. Atribut produk yang dirasakan konsumen memainkan peran penting dalam melindungi perilaku pembelian mereka. Persepsi konsumen terhadap suatu produk dan preferensi untuk atribut produk tertentu dapat memberikan informasi untuk memprediksi pilihan konsumen (Fishbein, 1963). Dalam melakukan penawaran produk kepada pelanggan, harus memperhatikan inti dan nilai tambah produk yang dapat memenuhi kebutuhan dan keinginan konsumen (Hashim \& Hamzah, 2014). Hal ini mengindikasikan bahwa kualitas produk dapat berpengaruh signifikan terhadap keputusan pembelian.

Harga dari suatu produk tentunya akan mempengaruhi perilaku pembelian seseorang. Harga memiliki aspek moneter dan non-moneter. Aspek moneter adalah harga objektif (Harga sebenarnya) dari suatu produk atau layanan, sedangkan aspek non-moneter adalah harga yang dirasakan oleh konsumen (Harga yang persepsikan) (Zeithaml, 1988). Ini dapat dinyatakan bahwa harga suatu produk dapat memberikan wawasan tentang nilai-nilai yang dimiliki oleh suatu produk (Išoraitè, 2016). Harga yang sesuai dengan keinginan konsumen akan mempengaruhi keputusan dalam membeli produk (Rafdinal \& Suhartanto, 2020). Ini berarti semakin sesuai harga dengan persepsi konsumen, semakin tinggi kemungkinan konsumen akan membeli produk atau layanan mengingat semua faktor lainnya tetap konstan. Sehingga, hipotesis yang dibangun adalah sebagai berikut:

H5. Kualitas produk berpengaruh signifikan terhadap perilaku berbelanja online

H6. Harga berpengaruh signifikan terhadap perilaku berbelanja online

\section{Metode Penelitian}

Populasi dalam penelitian ini adalah orang yang berbelanja di pada beberapa aplikasi toko online di Indonesia. Dalam penelitian ini teknik sampling yang digunakan adalah menggunakan simple random sampling. pengambilan anggota sampel dari populasi secara acak tanpa memperhatikan strata yang ada dalam populasi itu" Sehingga sampel yang digunakan pada penelitian ini berjumlah 300 responden. Instrumen yang digunakan dalam penelitian ini adalah kuesioner. Instrumen perilaku pembelian online dan kenyamanan berdasarkan penelitian (Pham \& Ahammad, 2017). Instrumen kepercayaan, kemudahan, dan keamanan didasarkan pada penelitian (Agag \& El-Masry, 2016). Kemudian indicator kualitas produk, dan harga berdasarkan penelitian (Rafdinal \& Suhartanto, 2020). Teknik analisis yang digunakan dalam penelitian ini yaitu tructural Equation Modeling (SEM) berbasis variance atau Partial least square (SEM-PLS). Teknik ini dikenal untuk memperkirakan koefisien jalur dalam model struktural (Hair et al., 2017). Ada dua tahap dalam analisis SEM-PLS, yaitu menganalisis model pengukuran dan menganalisis model struktural. Teknik analisis data ini dipilih karena memungkinkan peneliti menganalisis konstruk laten dengan ukuran sampel sedang dan kecil, dan bila distribusi datanya tidak normal (Chin et al., 2008). 


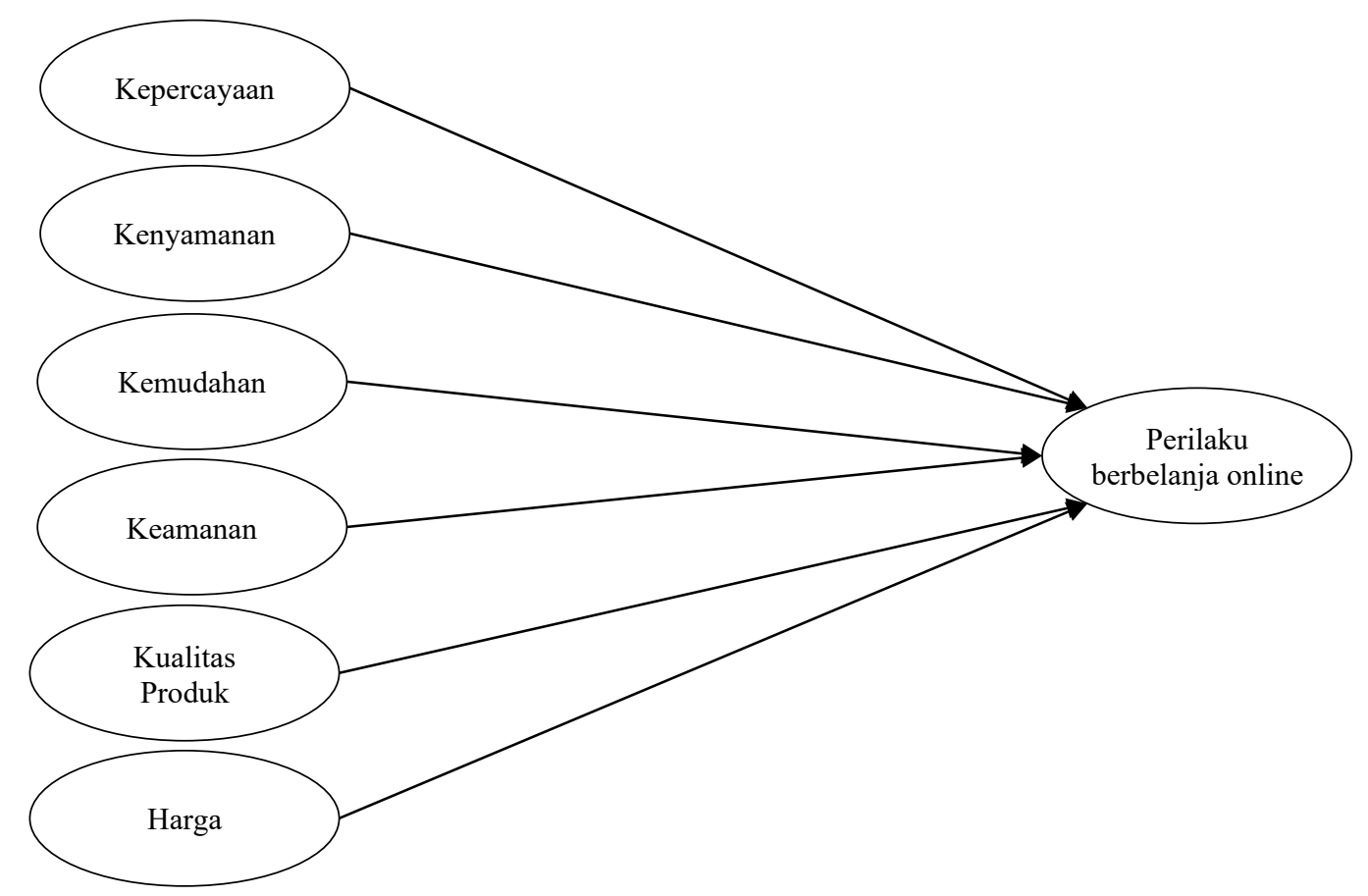

Gambar 1. Kerangka Konseptual

\section{Hasil dan Pembahasan}

\section{Karakteristik responden}

Tabel I menampilkan karakteristik responden.

Tabel 1. Karakteristik responden

\begin{tabular}{|l|l|l|l|}
\hline Variabel & Deskripsi & Frekuensi & $(\%)$ \\
\hline \multirow{3}{*}{ Jenis kelamin } & Wanita & 140 & $33,6 \%$ \\
\cline { 2 - 4 } & Pria & 71 & $66,4 \%$ \\
\hline \multirow{3}{*}{$\begin{array}{l}\text { Fendidikan } \\
\text { penggunaan } \\
\text { aplikasi toko online }\end{array}$} & Pelajar & 21 & $10 \%$ \\
\hline \multirow{4}{*}{$\begin{array}{l}\text { Aplikasi } \\
\text { digunakan }\end{array}$} & D-1 hingga D-3 & 13 & $6,2 \%$ \\
\cline { 2 - 4 } & Sarjana/setara & 177 & $83,8 \%$ \\
\cline { 2 - 4 } & 4-3 kali/bulan & 129 & $61,1 \%$ \\
\cline { 2 - 4 } & $7-9$ kali/bulan & 44 & $20,9 \%$ \\
\cline { 2 - 4 } & Shopee & 15 & $7,1 \%$ \\
\cline { 2 - 4 } & Tokopedia & 23 & $10,9 \%$ \\
\cline { 2 - 4 } & Lazada & 163 & $77,3 \%$ \\
\cline { 2 - 4 } & Lainnya & 15 & $13,7 \%$ \\
\hline
\end{tabular}

\section{Measurement model (model pengukuran)}

Dalam evaluasi model pengukuran, validitas konvergen dan validitas diskriminan dianalisis. Dalam mengevaluasi validitas konvergen, nilai composite reliability (CR) dan Cronbach 'alpha untuk setiap konstruk seharusnya lebih tinggi dari 0,7 (Chin, 1998). Selanjutnya, nilai average variance extracted (AVE) lebih tinggi dari nilai yang disarankan 0,5 (Hair et al., 2017).

Tabel 2. Hasil model pengukuran 


\begin{tabular}{|l|c|c|c|c|}
\hline Construct/item & Loading & $\begin{array}{c}\text { Cronbach' } \\
\text { alpha }\end{array}$ & CR & AVE \\
\hline Kepercayaan & & 0,921 & 0,950 & 0,864 \\
\hline Saya percaya bahwa aplikasi toko online ini dapat dipercaya & 0,939 & & & \\
\hline Aplikasi toko online ini dapat diandalkan & 0,938 & & & \\
\hline Aplikasi toko online ini memiliki integritas & 0,911 & & & \\
\hline Kenyamanan & & 0,907 & 0,932 & 0,773 \\
\hline $\begin{array}{l}\text { Saya nyaman menggunakan aplikasi toko online ini karena dapat } \\
\text { diakses kapanpun }\end{array}$ & 0,914 & & & \\
\hline $\begin{array}{l}\text { Saya nyaman menggunakan aplikasi toko online ini karena mudah } \\
\text { menemukan produk }\end{array}$ & 0,867 & & & \\
\hline $\begin{array}{l}\text { Saya nyaman menggunakan aplikasi toko online ini karena } \\
\text { informasi yang tersedia }\end{array}$ & 0,869 & & & \\
\hline $\begin{array}{l}\text { Saya nyaman menggunakan aplikasi toko online ini karena } \\
\text { kenyamanan bertransaksi }\end{array}$ & 0,866 & & & \\
\hline Kemudahan & & 0,831 & 0,914 & 0,842 \\
\hline Saya pikir belajar menggunakan aplikasi toko online ini mudah & 0,865 & & & \\
\hline $\begin{array}{l}\text { Menurut saya, proses pemesanan melalui toko online inin tidak } \\
\text { membutuhkan banyak usaha }\end{array}$ & 0,968 & & & \\
\hline Keamanan & & 0,701 & 0,866 & 0,764 \\
\hline $\begin{array}{l}\text { Saya tidak khawatir tentang privasi informasi pribadi saya selama } \\
\text { transaksi melalui toko online ini }\end{array}$ & 0,879 & & & \\
\hline $\begin{array}{l}\text { Toko online ini menerapkan langkah-langkah keamanan untuk } \\
\text { melindungi data pengguna }\end{array}$ & 0,868 & & & \\
\hline Kualitas produk & & 0,706 & 0,862 & 0,758 \\
\hline $\begin{array}{l}\text { Terdapat banyak pilahan produk berkualitas pada aplikasi toko } \\
\text { online ini }\end{array}$ & 0,908 & & & \\
\hline Terdapat garansi produk & 0,831 & & & \\
\hline Harga & & 0,768 & 0,850 & 0,587 \\
\hline Harga ditampilkan dengan jelas & 0,772 & & & \\
\hline Tidak terdapat tambahan biaya dari yang ditampilkan toko & 0,710 & & & \\
\hline Harga Sesuai Kualitas & 0,856 & & & \\
\hline Harga lebih murah dari aplikasi toko online lainnya & 0,718 & & & \\
\hline Perilaku pembelian & & 0,883 & 0,928 & 0,811 \\
\hline Saya akan lebih sering menggunakan aplikasi toko online ini & 0,871 & & & \\
\hline Saya akan terus berbelanja pada toko online ini & 0,937 & & & \\
\hline Saya akan terus menggunakan aplikasi toko online ini & 0,893 & & & \\
\hline
\end{tabular}

Tabel 3 menunjukkan hasil loading factor yang valid dengan skor di atas 0,7; Oleh karena itu, indikator tersebut dapat digunakan dalam model penelitian. Validitas diskriminan divalidasi dengan kriteria Fornell-Larcker. Dari hasil uji validitas diskriminan, akar kuadrat dari setiap nilai konstruk AVE memiliki nilai yang lebih tinggi dari korelasi konstruk dengan variabel laten lainnya (Fornell \& Larcker, 1981) Akar kuadrat AVE masing-masing konstruk lebih tinggi dari varian bersama antar konstruk, seperti yang ditunjukkan pada Tabel 4. Oleh karena itu, validitas diskriminan diterima.

Tabel 3. Discriminant validity (Fornell-Larcker criterion)

\begin{tabular}{|c|c|c|c|c|c|c|c|}
\hline & 1 & 2 & 3 & 4 & 5 & 7 & 8 \\
\hline 1. Harga & 0,766 & & & & & & \\
\hline 2. Keamanan & 0,489 & 0,874 & & & & & \\
\hline 3. Kemudahan & 0,524 & 0,535 & 0,918 & & & & \\
\hline 4. Kenyamanan & 0,556 & 0,365 & 0,596 & 0,879 & & & \\
\hline 5. Kepercayaan & 0,544 & 0,478 & 0,479 & 0,554 & 0,929 & & \\
\hline 7. Kualitas_Produk & 0,603 & 0,497 & 0,500 & 0,628 & 0,533 & 0,870 & \\
\hline
\end{tabular}




\section{Structure model}

Berdasarkan hasil perhitungan SEM PLS menunjukkan kepercayaan berpengaruh signifikan terhadap perilaku berbelanja online $(\beta=0,255 ; p=0,000)$, kenyamanan juga memiliki pengaruh yang signifikan terhadap perilaku berbelanja online $(\beta=0,309 ; \mathrm{p}=0,000)$. Kemudahan berpengaruh signifikan terhadap perilaku berbelanja online $(\beta=0,144 ; p=0,008)$. Kemudian, keamanan berpengaruh signifikan terhadap perilaku berbelanja online $(\beta=0,463 ; p=0,000)$. Selanjutnya, kualitas produk tidak berpengaruh signifikan terhadap perilaku berbelanja online $(\beta=-0,039 ; p=0,813)$ dan harga $(\beta=-0,013 ; p=0,779)$. Hasil ini menunjukan bahwa factor persepsi pribadi yaitu kepercayaan, kenyamanan, kemudahan, dan keamanan berpengaruh signifikan terhadap perilaku berbelanja online. Tetapi, kualitas produk dan harga tidak berpengaruh signifikan terhadap perilaku berbelanja online.

Tabel 4. Pengaruh antar variabel

\begin{tabular}{|l|c|c|c|l|}
\hline Variables & $\begin{array}{c}\text { Path } \\
\text { coeficient }\end{array}$ & $\begin{array}{c}\mathrm{T} \\
\text { Statistics }\end{array}$ & $\begin{array}{c}\mathrm{P} \\
\text { values }\end{array}$ & Result \\
\hline H1. Kepercayaan -> Perilaku berbelanja online & 0,255 & 5,075 & 0,000 & Accepted \\
\hline H2. Kenyamanan -> Perilaku berbelanja online & 0,309 & 5,714 & 0,000 & Accepted \\
\hline H3. Kemudahan -> Perilaku berbelanja online & 0,144 & 2,638 & 0,008 & Accepted \\
\hline H4. Keamanan -> Perilaku berbelanja online & 0,463 & 9,872 & 0,000 & Accepted \\
\hline H5. Kualitas produk - Perilaku berbelanja online & $-0,039$ & 0,237 & 0,813 & Rejected \\
\hline H6. Harga -> Perilaku berbelanja online & $-0,013$ & 0,280 & 0,779 & Rejected \\
\hline
\end{tabular}

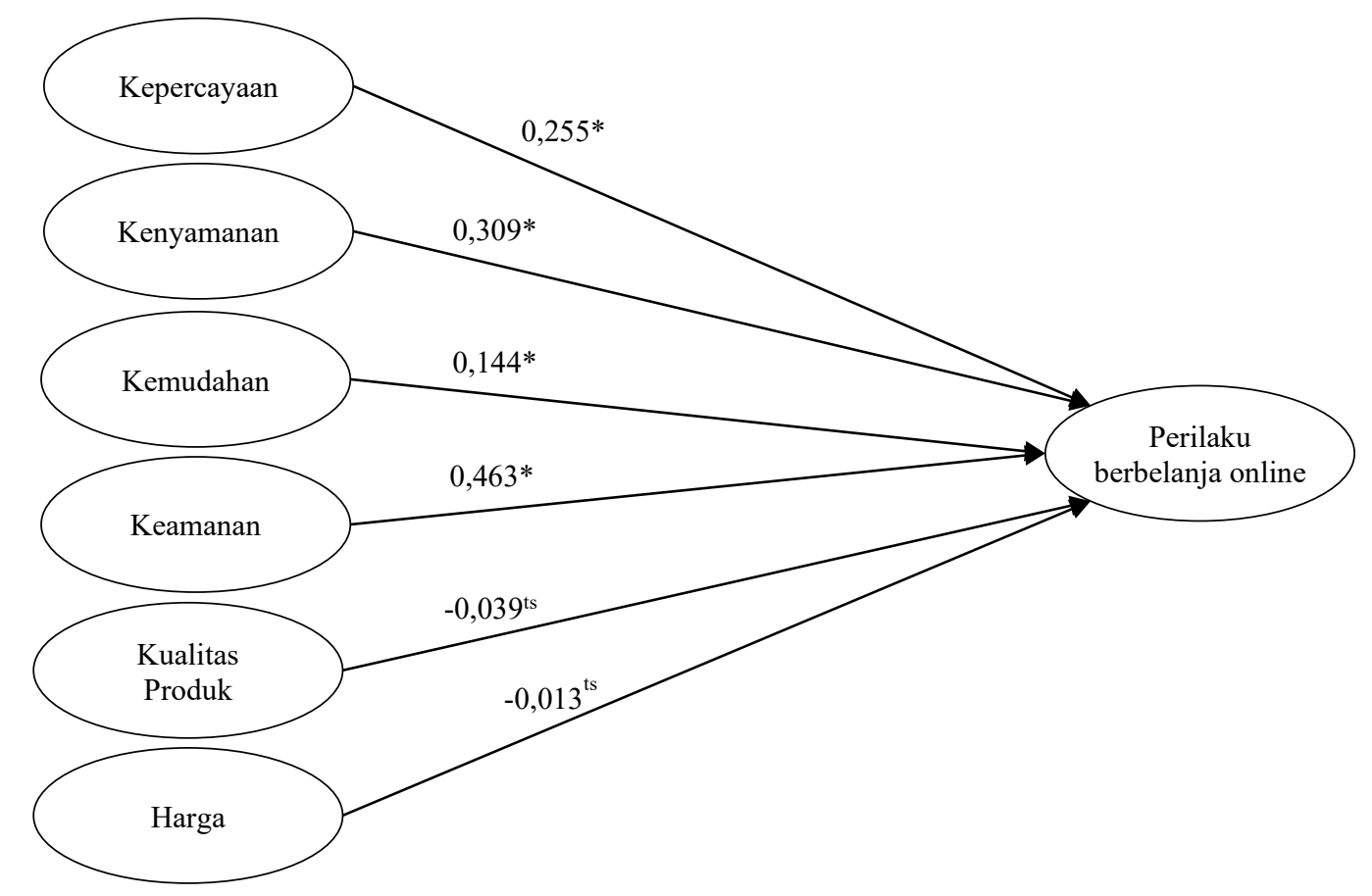

Note. *sig. 0.05 ; ts. tidak signifikan

Gambar 2. Model hasil penelitian

\section{Diskusi dan Pembahasan}

Hasil penelitian ini menunjukan bahwa model penelitian ini adalah model yang memiliki kekuatan prediktif yang baik dalam menganalisis perilaku berbelanja online selama pandemic Covid-19. Hal ini dilihat dari nilai $\mathrm{R}^{2}$ sebesar $69,3 \%$ yang menunjukan pengaruh factor persepsi pribadi dan factor penyedia layanan yang cukup tinggi terhadap perilaku berbelanja online. Perilaku pembelian merupakan 
hasil dari rangkaian kegiatan yang dilakukan konsumen dalam mengidentifikasi kebutuhan, mencari informasi, mengevaluasi beberapa alternatif, dan memilih yang tepat (Rafdinal, 2019). Hasil penelitian ini memberikan pengetahuan bahwa model perilaku pembelian online selama covid-19 dibentuk dari factor persepsi pribadi (kepercayaan, kenyamanan, kemudahan, dan keamanan) dan factor penyedia produk (kualitas produk dan harga).

Pada faktor persepsi pribadi, hasil temuan menunjukkan bahwa kepercayaan, kenyamanan, kemudahan, dan keamanan memiliki pengaruh positif dan signifikan terhadap perilaku berbelanja online pada masa pandemic Covid-19. Oleh karena itu, motivasi individu muncul sebagai anteseden keterlibatan konsumen yang memainkan peran utama dalam mempengaruhi perilaku pembelian offline yang sebenarnya (Dabbous \& Barakat, 2020). Harker \& Egan (2006) menegaskan bahwa bagian sentral dari pemasaran relasional adalah interaksi antarpribadi antara penjual dan pembeli. Tujuan komprehensif dari pemasaran relasional adalah untuk memiliki pelanggan jangka panjang dan pentingnya hal itu jelas karena lebih murah mempertahankan pelanggan dibandingkan mendapatkan pelanggan baru (Jalilvand et al., 2017). Faktor persepsi konsumen atas layanan yang diberikan merupakan factor penting yang mempengaruhi perilaku berbelanja online. Hasil penelitian ini memberikan bukti bahwa factor persepsi pribadi seperti kepercayaan kepada toko online, persepsi kenyamanan dalam berbelanja secara online, persepsi kemudahan dalam setiap proses belanja, dan perspsi keamanan merupakan factor penting dalam mempengaruhi perilaku berbelanja secara online selama pandemic Covid-19.

Hasil penelitian ini membutikan bahwa kualitas produk dan harga tidak berpengaruh signifikan terhadap perilaku berbelanja online. Dalam aplikasi toko online, banyak produk sejenis yang tersedia. Konsumen bebas memilih produk mana yang akan mereka beli. Hal ini memberikan bukti bahwa factor kualitas produk saja tidak mempengaruhi perilaku pembelian produk. Tetapi, nilai tambah yang didapatkan oleh konsumen dari produk tersebut yang akan mengarahkan konsumen pada pilihan produk. Dalam melakukan penawaran produk kepada pelanggan, harus memperhatikan inti dan nilai tambah produk yang dapat memenuhi kebutuhan dan keinginan konsumen (Hashim \& Hamzah, 2014). Dalam suatu aplikasi toko online terdapat banyak toko yang menawarkan harga yang murah. Tetapi harga yang murah tidak menjamin seseorang akan membeli. Harga suatu produk dapat memberikan wawasan tentang nilai-nilai yang dimiliki oleh suatu produk (Išoraitė, 2016). Hasil penelitian ini memberikan bukti bahwa kualitas produk dan harga bukan merupakan factor utama yang mempengaruhi perilaku berbelanja online selama masa pandemic Covid-19

Sebagai kesimpulan, hasil ini menunjukkan tiga kesimpulan penting. Pertama, model yang dibangun memverifikasi kekuatan eksploratif perilaku pembelian secara online selama pandemic Covid-19. Hal ini terbukti dari nilai $\mathrm{R}^{2}$ pada model penelitian ini yang tinggi. Sehingga, penelitian ini dapat memberikan pemahaman baru dalam model perilaku pembelian secara online selama pandemic Covid19. Kedua, studi ini merupakan salah satu dari sedikit studi di bidang perilaku pembelian pada situasi khusus yaitu pandemic Covid-19 yang menganalisis persepsi individu dan penyedia produk. Faktorfaktor seperti kepercayaan, kenyamanan, kemudahan, dan keamanan telah terbukti sebagai factor yang mempengaruhi perilaku pembelian secara online selama pandemic Covid-19. Ketiga, hasil penelitian ini dapat memberikan pemahaman mengenai perilaku pembelian online dalam konteks konsumen dari negara berkembang, Indonesia.

Secara praktis, terdapat beberapa implikasi penting dalam penelitian ini. Pertama, kepercayaan, kenyamanan, kemudahan, dan keamanan merupakan factor penting dalam mempengaruhi perilaku pembelian online. Berbagai pihak seperti penyedia aplikasi toko online ataupun pengembang aplikasi perlu memperhatikan factor persepsi pribadi ini dalam mendesain dan mengembangkan aplikasi toko online. Aplikasi harus memberikan kepercayaan kepada pengguna bahwa transaksi akan berjalan lancer hingga produk diterima, memberikan kenyamanan kepada pengguna dalam berbelanja, memberikan kemudahan dalam setiap proses belanja hingga pembayaran, dan menjamin kemanan data pengguna. Untuk itu, diperlukan perbaikan secara terus menerus pada aplikasi toko online yang sesuai dengan persepsi pengguna. 
Kedua, setiap penyedia aplikasi toko online perlu memastikan bahwa merchant atau toko online yang terdaftar dalam aplikasi memberikan produk yang berkualitas dengan reputasi yang baik dan harus memilikim nilai tambah. Kekecewaan pembeli atas kualitas produk yang dibeli pada suatu toko perlu diberikan teguran oleh pihak penyedia aplikasi sehingga toko online dapat terus memberikan produk yang berkualitas. Selain itu, tidak dapat dipungkiri bahwa dalam pasa online, harga yang ditawarkan sangat bersaing. Pihak penyedia perlu memastikan bahwa toko online yang memberikan harga murah dapat menjamin produk yang mereka jual memiliki kualitas yang baik. Sehingga, konsumen mendapatkan produk yang berkualitas walaupun dengan harga yang terjangkau.

Penelitian ini telah mampu memperluas pemahaman kita tentang perilaku pembelian online pada masa pandemic Covid-19, namun masih terdapat beberapa keterbatasan yang harus diakui. Pertama, setiap penyedia aplikasi toko online memiliki fitur dan layanan yang berbeda yang akan mempengaruhi perilaku pembelian konsumen. Penelitian selanjutnya perlu menganalisis factor fitur dan layanan sebagai fokus penelitiannya sehingga perilaku pembelian online dapat dianalisis lebih lengkap. Kedua, mayoritas distribusi sampel berasal dari pulau Jawa yang dapat membatasi generalisasi dari temuan ini. Studi selanjutnya diharapkan dapat melengkapi variasi responden yang lebih luas dalam hal wilayah geografis untuk memperoleh generalisasi temuan yang lebih baik. Ketiga, penelitian ini terbatas pada konteks konsumen di Indonesia yang merupakan negara berkembang. Hasil temuan mungkin tidak dapat digeneralisasi pada negara lain yang lebih maju ataupun berada dibawah dalam hal pengguna internet.

\section{Daftar Pustaka}

Agag, G., \& El-Masry, A. A. (2016). Understanding the determinants of hotel booking intentions and moderating role of habit. International Journal of Hospitality Management, 54, 52-67. https://doi.org/10.1016/j.ijhm.2016.01.007

APJII. (2019). Buletin APJII Edisi-40 2019. Indonesia Internet Service Provider Association, 6. https://apjii.or.id/survei

Badan Pusat Statistik. (2019). Statistik e-commerce 2019. In Badan Pusat Statistik. https://www.bps.go.id/publication/2019/12/18/fd1e96b05342e479a83917c6/statistik-ecommerce-2019.html

Berry, L. L., Seiders, K., \& Grewal, D. (2002). Understanding service convenience. Journal of Marketing, 66(3), 1-17.

Blackwell, R. D., Miniard, P. W., \& Engel, F. J. (2006). Consumer Behaviour. Thomson.

Chaturvedi, S., Gupta, S., \& Hada, D. S. (2016). Perceived risk, trust and information seeking behavior as antecedents of online apparel buying behavior in India: An exploratory study in context of Rajasthan. International Review of Management and Marketing, 6(4), 935-943. https://doi.org/10.2139/ssrn.3204971

Chin, W. W. (1998). The Partial Least Squares Approach to Structural Modeling. Lawrence Erlbaum Associates, Inc.

Chin, W. W., Peterson, R. A., \& Brown, S. P. (2008). Structural equation modeling in marketing: Some practical reminders. Journal of Marketing Theory and Practice, 16(4), 287-298.

Cozzarin, B. P., \& Dimitrov, S. (2016). Mobile commerce and device specific perceived risk. Electronic Commerce Research, 16(3), 335-354.

Dabbous, A., \& Barakat, K. A. (2020). Bridging the online offline gap: Assessing the impact of brands' social network content quality on brand awareness and purchase intention. Journal of Retailing and Consumer Services, 53, 101966. https://doi.org/10.1016/j.jretconser.2019.101966

Fishbein, M. (1963). An investigation of the relationships between beliefs about an object and the attitude toward that object. Human Relations, 16(3), 233-239.

Fornell, C., \& Larcker, D. F. (1981). Evaluating Structural Equation Models with Unobservable Variables and Measurement Error. Journal of Marketing Research, 18(1), 39-50.

Hair, J. E., Hult, G. T., Ringle, C. M., \& Sarstedt, M. (2017). A primer on partial least squares structural equation modeling (PLS-SEM) (2nd ed.). Sage.

Han, H. (2015). Customer retention in the medical tourism industry: Impact of quality, satisfaction, trust, 
and price reasonableness. Tourism Management, 46, 20-29. https://doi.org/10.1016/j.tourman.2014.06.003

Harker, M. J., \& Egan, J. (2006). The past, present and future of relationship marketing. Journal of Marketing Management, 22(1-2), 215-242.

Hashim, N., \& Hamzah, M. I. (2014). 7P's: A Literature Review of Islamic Marketing and Contemporary Marketing Mix. Procedia - Social and Behavioral Sciences, 130, 155-159. https://doi.org/10.1016/j.sbspro.2014.04.019

Hosseini, M., \& Norouzi, H. (2017). Investigating the impact of consumer trust on loyalty and purchase intention of food store brands: Case study: Palladium shopping mall in Tehran. International Review of Management and Marketing, 7(4), 138-146.

Howard, J. . (1989). Consumer Behavior in Marketing Strategy. Prentice-Hall.

Išoraite, M. (2016). Marketing mix theoretical aspects. International Journal of ResearchGranthaalayah, 4(6), 25-37. https://doi.org/10.5281/zenodo.56533

Jalilvand, M. R., Salimipour, S., Elyasi, M., \& Mohammadi, M. (2017). Factors influencing word of mouth behaviour in the restaurant industry. Marketing Intelligence and Planning, 35(1), 81-110. https://doi.org/10.1108/MIP-02-2016-0024

Jiang, L. A., Yang, Z., \& Jun, M. (2013). Measuring consumer perceptions of online shopping convenience. Journal of Service Management.

Lee, W. I., Cheng, S. Y., \& Shih, Y. T. (2017). Effects among product attributes, involvement, wordof-mouth, and purchase intention in online shopping. Asia Pacific Management Review, 22(4), 223-229. https://doi.org/10.1016/j.apmrv.2017.07.007

Lew, S., \& Sulaiman, Z. (2014). Consumer Purchase Intention toward Products Made in Malaysia vs. Made in China: A Conceptual Paper. Procedia - Social and Behavioral Sciences, 130, 37-45. https://doi.org/10.1016/j.sbspro.2014.04.005

Lin, W. B., Wang, M. K., \& Hwang, K. P. (2010). The combined model of influencing on-line consumer behavior. Expert Systems with Applications, 37(4), 3236-3247. https://doi.org/10.1016/j.eswa.2009.09.056

Moeller, S., Fassnacht, M., \& Ettinger, A. (2009). Retaining customers with shopping convenience. Journal of Relationship Marketing, 8(4), 313-329.

Mohmed, S. I., Azizan, B., \& Jali, Z. (2013). The Impact of Trust and Past Experience on Intention to Purchase in E-Commerce. International Journal of Engineering Research and Development, 7(10), 28-35.

Ollie. (2008). Membuat toko online dengan multiply. Media Kita.

Pham, T. S. H., \& Ahammad, M. F. (2017). Antecedents and consequences of online customer satisfaction: A holistic process perspective. In Technological Forecasting and Social Change (Vol. 124). https://doi.org/10.1016/j.techfore.2017.04.003

Rafdinal, W. (2019). Increasing purchase decisions on palm oil seeds through marketing mix and trust. Advances in Social Science, Education and Humanities Research, 354, 192-198. https://doi.org/10.2991/icastss-19.2019.41

Rafdinal, W., \& Suhartanto, D. (2020). Loyalty model for ethnic restaurants : The role of quality and value. International Journal of Applied Business Research, 2(2), 123-138. https://doi.org/10.35313/ijabr.v0i0.104

Rose, S., Clark, M., Samouel, P., \& Hair, N. (2012). Online customer experience in e-retailing: an empirical model of antecedents and outcomes. Journal of Retailing, 88(2), 308-322.

Roy, S. K., Lassar, W. M., \& Shekhar, V. (2016). Convenience and satisfaction: mediation of fairness and quality. The Service Industries Journal, 36(5-6), 239-260.

Seiders, K., Voss, G. B., Godfrey, A. L., \& Grewal, D. (2007). SERVCON: development and validation of a multidimensional service convenience scale. Journal of the Academy of Marketing Science, 35(1), 144-156.

Srinivasan, S. S., Anderson, R., \& Ponnavolu, K. (2002). Customer loyalty in e-commerce: an exploration of its antecedents and consequences. Journal of Retailing, 78(1), 41-50. 
Szymanski, D. M., \& Hise, R. T. (2000). E-satisfaction: an initial examination. Journal of Retailing, 76(3), 309-322.

Tasin, N. B. (2017). Factors influecing customer's trust in online shopping among executives in a bank. Malaysian Journal of Social Sciences and Humanities (MJSSH), 2(3), 46-59.

Wang, C., \& Chen, C. (2009). The Impact of Knowledge and Trust on E-Consumers ' Online Shopping Activities : An Empirical Study. Journal of Computers, 4(1), 11-18.

Yale, L., \& Venkatesh, A. (1986). Toward the construct of convenience in consumer research. ACR North American Advances.

Zeithaml, V. A. (1988). Consumer Perceptions Of Price, Quality, And Value : A Means-. Journal of Marketing, 52(3), 2-22.

\section{*Email korespondensi:}

nugroho.hardiyanto@polban.ac.id 